\title{
Determinants of Customers' Bank Selection Decision in the Mfantsiman Municipality of Ghana
}

\author{
Godfred Bugyei \\ Master of Commerce, Assistant Director, Ghana Education Service PO box sp 67, Saltpond
}

\begin{abstract}
The prominence of financial institutions in the development of an economy is well established. In Ghana various reforms in the financial sector have made the Ghanaian banking industry an intensely competitive proposition. This study, investigated the determinants of customers' bank selection decision in the Mfantseman Municipality in Ghana. A descriptive cross-sectional survey research design was employed for the study. Data was acquired using self-administered questionnaires from bank customers. Multinomial logistic regression statistical method was used to analyse the data. The findings disclosed a significant relationship between customers' choice of bank and advertising, branding, distance to bank location and types of electronic product offered by banks. It was recommended that banks should embark on aggressive advertising campaign on the benefits of their products and services, improve upon their brand image and financial stability. Banks should also come out with more electronic products that are relevant to the changing needs of potential customers.
\end{abstract}

Keywords: Selection Decision, Branding, Advertising, Location, Electronic Products, Banks

DOI: $10.7176 / \mathrm{EJBM} / 12-28-03$

Publication date:October $31^{\text {st }} 2020$

\section{Introduction}

Worldwide, communities and states have realised that baking is one of the pillars on which a nation's development spins around. Accordinmg to Demirguc-Kunt \& Klapper (2012), inclusive financial systems, allowing broad access to financial services, without price or non-price barriers to their use are especially likely to benefit the poor people and the disadvantaged group. Without inclusive financial systems, poor people need to rely on their limited savings to finance their children's education and small enterprises must rely on their limited earnings to pursue promising growth opportunities.

Aregbeyen (2011) opines that the issue of bank selection process has attracted considerable attention in the bank marketing literature, by researchers. Customers choose alternative financial service providers due to constraints, service quality and staff courtesy, among others (Cleopas \& Olawale, 2011). A competitive advantage can be reached by banks through product branding, which can successfully lead to several benefits such as less sensitive customers, decreased perceived risk among customers and increased brand loyalty (Keller, 2009). Blankson, Omar and Cheng (2009) orate that the banking industry in Ghana is characterized by increased competition since the early 1980s. The increased competition resulting from decades of deregulation of the financial service sector meant that banks are faced with the task of differentiating their organizations and products as a means of attracting customers. Develin and Mckenchie (2008) assert that in the marketing of financial institutions, corporate branding is essential. It is, therefore, crucial to understand how the brand is perceived by consumers and the impact it has on them (Kotler \& Keller, 2009). Keller (2009) points out that advertising contributes more in the form of brand equity only when, besides brand recall, it also produces favourable brand image and brand attitude. It is, therefore, key for commercial banks to understand the determinants of customers' bank selection decision so as to reduce the constraints of wealth maximization by the bank (Bramorski, Madan \& Matwon, 2002).

Airtel Ghana accentuated that, as at 2015, the unbanked population of Ghana's adult population increased to 80 percent due to the inability of the banks to develop innovative products that meet the needs of Ghanaians (http/www.graghic.com.gh).

In recent years, the banking sector in Ghana has undergone massive crisis and significant transformation. The central bank has therefore, developed new regulations and guidelines with the aim of maintaining stability in the financial market so as to promote strong and resilient economy. On August 14, 2017, the Central Bank of Ghana (BOG) approved a takeover of UT and Capital Bank by GCB Bank Limited. The Bank of Ghana stated that insolvency, related party transactions and bad corporate governance are the main reasons for the revocation of the licenses of the banks in question (Bank of Ghana, 2017).

Furthermore, on August 1, 2018, the Bank of Ghana, released a statement indicating the collapse of five indigenous banks to form a new bank called Consolidated Bank of Ghana Limited. The affected banks included uniBank, Royal Bank, Sovereign Bank, Construction Bank and Beige Bank Limited. The same reasons for the purchase and assumption of UT and Capital Bank were cited by the regulator for the consolidation of these five banks (http/www.ghanaweb.com.gh). It is, therefore, imperative to find out how the situation will affect the bank selection decision of potential customers in Ghana. 
Empirical studies such as (Cleopas \& Olawale, 2011; Shaher, Kasawneh \& Salem, 2011; Kumar, Kee \& Charles, 2010) have been carried out in the area of factors influencing customers' bank selection in many countries, such as, Canada, USA, Britain and Australia (Sharma \& Rao, 2010). However, limited empirical studies have focused on customers' choice of bank in Ghana and, particularly, in the Mfantsiman Municipality. This study, therefore, sought to examine the extent to which advertising, branding, distance and electronic products influence customers' choice of bank in the Mfantsiman Municipality of Ghana.

\section{Review of related Literature}

This section discusses the theoretical literature of the study, the empirical studies on factors that influence customers' bank selection decision and the conceptual framework for the study. The germane theoretical expositions underpinning this study are the theory of planned behavior and theory of constraint, rational choice theory and competition theory.

\subsection{The theory of Planned Behaviour}

Bandura (1997) stress that the theory of planned behaviour follows both cognitive and modified learning theory. Thus, even though a person thinks that a specific behaviour will produce positively valued outcomes, he or she will only be motivated to perform the behaviour to the extent that an individual is confident in the ability to perform it successfully. However, Beckett et al. (2003) argue that attitudinal factors, such as, involvement and uncertainty, also influence a consumer's behaviour. The more specific the result of the purchasing behaviour anticipated, the lower the degree of uncertainty and vice versa. The degree to which a product or a service can help a consumer to gain maximum satisfaction increases the consumer's desire to patronise the product at a specified period of time (Beckett et al., 2003). Ajzen (2002) suggests that when perceived behavioural control is understood by an individual that when subjective probabilities of success and actual control are less than perfect, the theory of planned behaviour is similar to Bandura's concept of self-efficacy, but only when the latter is defined in relation to the performance of specific behaviours. Rhodes and Courneya (2003) note that, despite the success of the theory of planned behaviour, its conceptualization has been controversial with regard to the perceived behavioural control. A symptom of this controversy is the disparity in the label used for the perceived behavioural control component. More importantly, there is a disparity in the definitions and the perception that perceived behavioural control is a multidimensional construct.

Leach, Hennessy and Fishbein (2001) assert that when the perceived behavioural control is operationalized in terms of perceived difficulty, it is just a complementary way of measuring attitude. They further postulate that it is not clear whether perceived behavioural control can really be differentiated from intentions. This is because consumers do not sometimes know what they want. They have unconscious needs and, therefore, advertisers are trying to make them to acquire what they do not necessarily need (Graves, 2010).

\subsection{The theory of constraint}

Customers of financial institution expect higher products and quality of services than the price they are willing to pay in order to acquire those products and services (Mabin \& Balderstone, 2003). According to Bramorski, Madan and Matwon (2002), the theory of constraint is applicable to banks, because they are faced with multiplicity of challenges, such as competition, increasing customer sophistication, government legislative and regulative control and technological advancement, because of the changing environment in which they operate. Also, due to globalization, banks strategically compete for customers using such dimensions as cost, flexibility, time and quality. The Theory of Constraints can be effectively used to identify an organization's goals, locate the challenges of achieving maximum performance and develop practical measurement to facilitate process improvements. Notwithstanding, it is sometimes difficult to identify the constraints that pose threat to the survival of businesses. The constraints in banks are mainly associated with the policies and procedures, rather than capacity or equipment. Therefore, this study admits that both the theory of planned behaviour and the theory of constraint underpin it.

2.3 The rational choice theory proposes a useful understanding on the selection behaviour of customers. The rational choice theory is a license for formally modeling social and economic behaviour. The theory hypothesizes that individuals make informed choices by maximize their benefits and minimize their costs. In other words, people make rational decisions by comparing the costs and benefits of different courses of action. Rational decision making requires choosing an action based on one's preferences, accomplishments and expectations about the outcomes of specified activities. The prudence of rational decision making is entrenched on two corresponding conventions, namely, completeness and transitivity. The importance of rational choice theory in this case, is where customers compare the costs and benefits of their actions in order to arrive at an optimum decision with respect to choosing the bank which is convenient to transact financial transaction with. Since bank customers want safety of their investment and to get worthwhile products and services at the lowest price and convenient location, they will judge the benefits of certain banks services to the other (Aregbeyen, 2011) 
2.4 The competition theory explicates how financial institutions such as banks try to attract and gain the commitment of customers by offering innovative products and services. Competition in economics is best described as the existence within a market for some good or service of a sufficient number of buyers and sellers such that no single market participant has enough influence to determine the prevailing price of the good or service. Competition occurs when two or more organizations act independently to supply their products to the same group of consumers. Most banks operating in Ghana offer similar products to their customers. It is, therefore, easy for customer to select a bank when the customer is dissatisfied or the distance to his or her primary bank location is convenient and the financial stability of the bank is not at stake. Competition causes banks to develop new products, services and technologies, which would give consumers alternatives choices and better satisfaction. Hull (2002) opines that the banking industry is highly competitive, with banks not only competing among each other, but also with non-banks and other financial institutions. Most bank products and services are easy to duplicate so they can only distinguish themselves on the basis of effective advertising, lower price and the quality of the product they offer to their customers.

In conclusion, customers of banks make their selection decision based multiple factors such as branding, advertising, safety of funds, convenient location of the bank, recommendation and product varieties. However, customers of banks are not bonded to any contractual relationship of transacting business with the same bank forever. Banks therefore can use effective advertising, build good reputation and develop unique products and services to attract potential customer and maintain loyal customers to stay in business.

\subsection{Customers' bank selection decision}

2.3.1 Advertising and customers' bank selection decision

Anon (2011) observes that newspapers, television and magazines have the biggest impact on consumer buying behaviour. When banks create the needed products and services, they must find the most effective method to make their existing customers aware of them and also inform the larger market. Advertising provides the greatest opportunity for business organisations to inform people about their existence and to remain competitive. Suntherland (2008) affirms that television adverts usually tend to have more of consumers' attention, since not only do they hear what the advertisers have to say, they also see what they can get. According to Kotler and Keller (2010), advertising is usually used by organisations to inform a larger audience about a product or service. By exposing consumers to repetitions and images of products, it increases the likelihood of buying (Jansson-Boyd, 2010). Mokhlis (2009) posits that marketing promotions influence both male and females when selecting their preferred bank for financial transactions.

In their recent study, Shaher, Kasawneh and Salem (2011) evaluated the major factors that affect the commercial banks' performance by customers in the Middle East Region. They employed factor analysis technique in their methodology in order to extract the most essential factors that hinder the customers in their choice of banks and banking services. Their finding revealed that banks' characteristics and awareness of banks' performance through advertisement are considered as important factors in customers' bank selection decision. A study was conducted by Abduh and Omar (2010) on the Indonesian customers' attitude. The target population of the study was the customers of Islamic banks in Indonesia. The finding of the study disclosed that banks' marketing and advertisement highly influence individuals in patronizing a particular bank. Moreover, customers prefer banks based on announcements of the bank on interest rate and safety of funds. Cengiz, Ayyildiz and Er (2007) studied the behaviour of bank customers' in Turkey. The finding of their study revealed that efficient advertisement may enhance bank customers' loyalty and help to retain customers. The study further pointed out that effective advertisement captures the attention of potential customers and advances customer loyalty. Moreover, professional service advertisement is positively associated with customers' expectations of benefit and guides their purchasing behavior.

\subsubsection{Reputation and customers' bank selection decision}

According to Bravo, Montaner and Pina (2010), another way to differentiate one bank from the other in this retail bank market is by using corporate brand image and reputation. This has become important due to the deregulated market and increased competition in the retail market.

In India, Rao (2010) conducted a research in the area of student banking. A sample of 312 respondents was selected to determine the factors that influence their decision to select banks with which to perform their financial transactions. The responses of the respondents indicated that brand name, employee's courtesy, and financial reliability of the bank influence their choice of bank.

In Malaysia, Kumar, Kee and Charles (2010) conducted a study to determine the factors that affect the decision of customers when making a choice of bank. The findings of the study revealed that branding is the most important factor considered by customers in selecting a bank for financial transactions. Kamakodi and Khan (2008) surveyed and obtained responses from 292 bank customers on the factors that influence their bank selection decision. The study revealed that the brand image of a bank is one of the top parameters customers consider when 
choosing commercial banks and their services. In his research, Mylonakis (2007) studied customer preferences in the home loan market experience in Greece. He sampled 200 bank customers and collected the data, using structured questionnaire. His findings disclosed that the bank's reputation, existing co-operation as well as the attitude of bank staff are the major factors that influence customers' choice of bank.

Clemes, Gan and Zhang (2010) posit that reputation depends on three elements, namely the reliability of the bank, trust worthiness and financial stability of the bank. Kotler and Keller (2006) observe that although competitors can duplicate the manufacturing process and the product design, they cannot match the lasting impressions in the minds of individuals from years of marketing activities and product experience.

\subsubsection{Convenient location and customers' bank selection decision}

Customers tend to switch to a new provider if the new provider is closer to their home or workplace, because it directly determines whether the customer can access their banks on a regular basis (Gnash, Arnold \& Reynolds, 2000). Therefore, relocation or other factors beyond the control of the customer or service provider can destroy even the most satisfied relationship between the customer and the service provider (Taylor, Roos \& Hammer, 2009). Selleh and Hazimah (2009) assert that customers always try to select those banks which have more branches and are convenient in location. Location has a special meaning in the financial service industry, because it is at the branch or office that a bank and its customers are connected; it is where the customers have their accounts. A convenient location can encourage customers to stay at their current bank and delay the idea of switching, even if the satisfaction rate is not high (Lee \& Cunningham, 2004).

Maiyaki (2011) conducted a survey in Nigeria to obtain information about the factors determining the selection and preference of commercial banks by retail customers. He sampled 417 bank customers, using multistage sampling procedure. He discovered that the availability of large branch network across the country and the convenient access to bank location were some of the greatest influence on customers' choice of bank. In Afghanistan, Farooq, Ahmad and Jamil (2010) studied the decision criteria of Islamic bank customers when patronizing a particular bank. The result of the study revealed that access to bank is one of the most important factors leading to customer's choice for the selection of banking products and services. Blankson et al. (2009) employed a comparative cross-national study aimed at revealing the factors that determine retail bank selection among students in different environmental settings. The findings of the study disclosed that convenient location is the most important factor that influences students' bank service selection in Ghana and United States. Similarly, Mokhlis, Mat and Salle (2008) conducted a research in Malaysia. They sampled 350 undergraduate students to identify the factors which determine their bank selection decisions and to determine whether undergraduates constitute a homogeneous group in relation to the way they select banks. Adopting factor analysis technique, they found out that proximity and branch location were grouped as moderate factors that influence student bank selection.

In Malaysia, Dusuki and Abdullah (2007) conducted a study on customers' bank selection decision. They used self-administered questionnaire as the main data collection instrument. The sample size for the study was 750 respondents. They also employed banking criteria ranking as perceived by the respondents and analysed the data, using Friedman Test. The study revealed that the most significant determinant for choosing a bank as perceived by respondents is convenient location. Kisser (2002) conducted a research and inferred that, due to time and cost constraints, many customers give value to the nearest bank branch and open their accounts in these branches. He further asserted that clients may prefer to select the nearby bank from either their residential place or work place, especially when there is narrow geological ease of access to substitute banks. The distance to bank branches that are favourable plays a major role to attract customers who are more interested about convenient location of banks, because it saves their time and cost as well.

\subsubsection{Electronic products and customers bank selection decision}

Innovation and completion have influenced banks to develop different electronic products to attract young potential customers. The primary drivers of innovation include, financial pressures to decrease costs and increase efficiency, increased competition, shorter product life cycles, value migration, stricter regulations, industry and community needs for sustainable development, increased demand for accountability, community and social expectations and pressures, demographic, social and market changes, rising customer expectations regarding service and quality product.

In Ghana, Abbam, Say and Carsamer (2015) conducted a survey to find out the factors influencing the choice of students' commercial bank. The study revealed that the most important factors that university students consider when choosing commercial banks are recommendation from parents and availability of ATM facility.

Maiyaki (2011) in his survey in Nigeria obtained information about the factors determining the selection and preference of banks by retail bank customers. The sample size used for the study was 417 bank customers. He adopted the multi-stage sampling procedure and found out that opportunity of telephone banking, availability of assorted retail bank services, reasonable terms of credit and loans repayment were the factors that have the least 
influence on customer choice of banks. In Turkey, a research was conducted by Katircioglu, Fethi, Unlucan and Dalci (2011) to investigate the selection criteria of undergraduate students who are considered as the future potential customers of banks in different regions of the world. Their finding revealed that availability and convenient location of Automated Teller Machine (ATM) services and speed and quality of services are the most important factors which are considered by both Turkish and non-Turkish undergraduate students when choosing and patronizing commercial banks and their services. In Pakistan, another study was conducted by Rahman and Ahmed (2008) to analyse the major determinants of customers' bank selection. The study was based on a survey of 358 customers of private, privatized and nationalized banks located in the city of Lahore. The finding of the study revealed that the most important factors influencing customers' choice of bank were customer services, convenience, online banking services and the overall banking environment. Sweeny and Morrison (2006) note that many innovations have recently modified the concept of retail banking due to the new forms of distribution of financial services as well as the evolution of the twenty-first century. Joseph and Stone (2003) also assert that the installment of customer friendly technology (such as, menu-driven automated teller machines, telephone and internet banking service) has become commonplace in recent years as a way of maintaining customer loyalty and increasing market share. Thus, new products and services are used as important instrument even though they contain certain risk (Littler \& Melanthiou, 2006). Abor (2004) argues that the most revolutionary electronic innovation in Ghana and the world over has been the ATM.

\subsection{Conceptual Framework for the Study}

The figure illustrates the relationship between bank selection decision and the variables of interest for the study, which are demographic characteristics, advertising, branding, distance to bank location and electronic products and services.

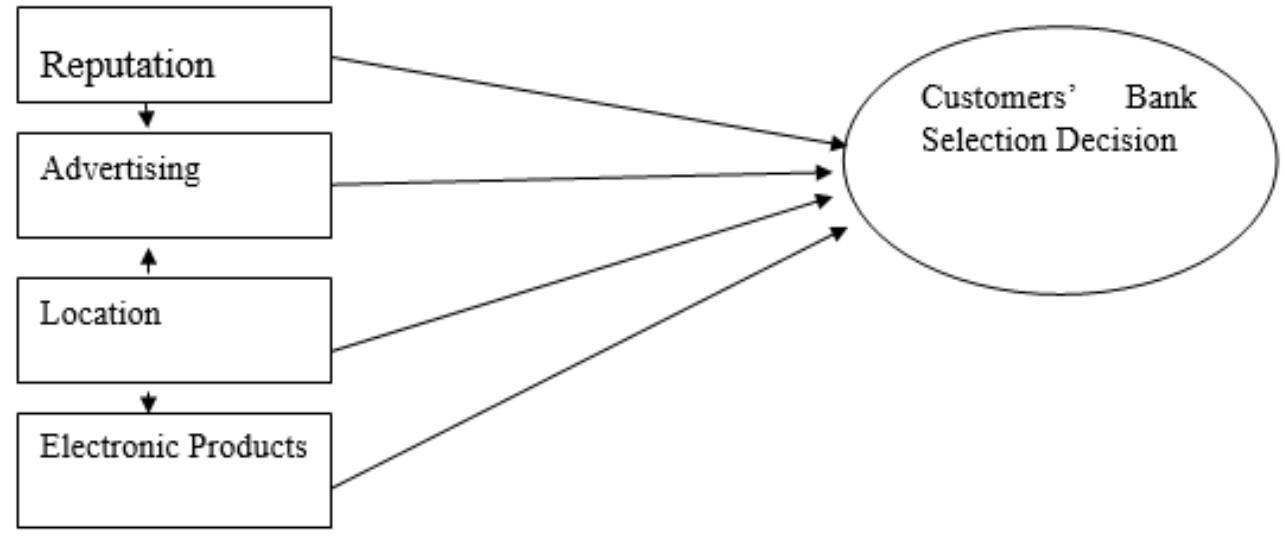

Figure 1: A conceptual framework illustrating the relationship between customers' bank selection decision and other factors

Source: Author's construct, 2020

The conceptual framework, as shown by Figure 1, demonstrates the influence that the explanatory variables of this study have on the dependent variable. Studies have proven that these explanatory variables (age, occupation, income, advertising, reputation, convenient location and electronic products) influence the decision of customers to choose a bank for financial transactions. Some of those empirical studies are Maiyaki, 2011; Katircioglu, 2011; Shaher et al., 2011; Rao, (2010); Shama, (2010); Mokhlis, 2009; It was, therefore, deemed prudent for these explanatory variables to be chosen as the variables of interest for this study under consideration.

\section{Research methodology}

\subsection{Study Design}

The study employed quantifiable research design. Creswell (2009) observes that the positivists believe in the application of quantitative method as a means for testing objectives and by examining the relationship among variables. Following the objectives of this study, a descriptive cross-sectional design was adopted for the study. This was considered appropriate, since the study involved the description of determinants of customers' bank selection decision. Cohen, Manion and Morrison (2011) expounded that descriptive design provides a meaningful picture of events under consideration. The survey strategy is also perceived as authoritative by people in general and it is comparatively easy to understand (Saunders, Lewis \& Thornhill, 2007). Data gathered through the survey together with a questionnaire are standardised and permit easy comparison.

\subsection{The study Area}

The study was conducted in the Mfantsiman Municipality of Ghana. Mfantsiman Municipality is one of the 17 
district assemblies in the Central Region of Ghana. The municipality is bounded on the South by the Atlantic Ocean, west by Cape Coast Metropolis, east by Ekumfi District and north by Ajumako District. It is geographically located between latitude $5^{0}$ south to $5.12^{0}$ north and longitude $1^{0}$ east and $1.4^{0}$ west. The total land area covered by the municipality is 533 kilometers square. It is the smallest metropolis in Ghana. The capital, Saltpond, used to be the ancient commerce hub of the Gold Coast, currently, Ghana. The inhabitants are mainly employed by farming, fishing and trading. The metropolis can boast of numerous saving and loans companies, rural banks and commercial banks. Most of these banks have obtained universal banking license to provide commercial banking, merchant banking and development banking to satisfy the needs of their customers. The banks operating in the Mfants 1man Metropolis include GCB Bank, Agricultural Development Bank, Microfin Bank and Nyankomansi Ahenkro Rural Bank

\subsection{Population and sample}

The population for this study consisted of all the customers of banks operating in the Mfantsiman Municipality. The study employed a convenience sampling technique. A convenient sampling technique was used in selecting the sample size 560 customers for the study. Convenience sampling relies on available participants who agree to participate in a study (Polit \& Beck, 2010)

\subsection{Instrumentation}

This study used self-administered questionnaire as the main instrument for the data collection. The questionnaires were structured and respondents were required to tick only one option to reflect their perception. Kusi (2012) and Adentwi et al. (2010) relate advantages of using questionnaire such as quick analysis, research participants feeling more comfortable in responding to pre-determined responses than items that require them to express their opinions, and anonymity of data collected. The questionnaire covered areas such as demographic characteristics of customers, advertising and information sources, branding, convenient bank location and electronic products and services. Choice of bank, branding, advertising, distance to bank location and electronic products were measured with a five-point Likert-type of rating scale, with the point being: Strongly agree $=5$; Agree $=4$; Somewhat agree $=3$; Disagree $=2$ and Strongly disagree $=1$. The Likert scale is the most widely used method of scaling in the social sciences (Title \& Hill, 1967).

\subsection{Data Analysis}

Prior to the analysis quantitative data, the data was cleaned and poorly answered questionnaires were eliminated. In all, 500 out of the 560 administered questionnaires were deemed appropriate for analysis. Data gathered from the field were edited to guarantee cohesion and reliability of information acquired. Edited data were processed electronically using the Statistical Product for Service Solution (SPSS 22.0 version). This made the analysis quicker and expedient. Multinomial logistic regression and Marginal effects results were derivered, using the Stata software (version 13) to determine the association between the dependent and the independent variables. The descriptive statistics were presented in tables for clear understanding of results.

\subsection{Research Hypotheses}

Based on previous empirical studies regarding the determinants of customers' bank selection decision, the following hypotheses have been cultivated and empirically tested.

H1: There exists significant relationship between demographic factors and customers bank selection decision.

H2: A significant correlation exists between electronic product (ATM service, mobile banking, internet banking \& E-zwich) and customers' bank selection decision.

H3: Advertising has significant influence on customers' bank selection decision.

H4: Bank's reputation and its image have a relation with customers' bank selection decision. H5: convenience location has effect on customers' bank selection decision.

\section{Results and Discussion}

This chapter examines the data and discusses the principal findings of the study. The first section deals with the descriptive analysis and the second section presents the regrssion results of the variables of interest of the study. The study focused on four main variables: advertising, branding, location of banks and innovative electronic products offered by banks - and how they influence respondents' bank selection decision. It can be concluded that branding, advertising, distance and electronic products had strong relationship with customers' bank selection decision. Moderate and significant relationship was found between demographics variables and customers' bank selection decision. All the variables of interest in the conceptual framework were found to be significant in explaining customers' bank selection decision in the Mfantsiman Municipality of Ghana. 
4.1 Demographic Characteristics of Customers of Banks operating in the Mfantseman Municipality

This part of the study explains the demographic characteristics of the bank customers in the Mfantseman Municipality. Information such age, sex, educational level and occupation were obtained from respondents. Responses were gathered from five hundred respondents who agreed to participate in the study and offered the appropriate responses.

Table lindicates that, among the 500 respondents, $311(62.20 \%)$ were males and $189(37.80 \%)$ were females. This result corroborates the finding of Demirgu-Kunt and Klapper (2012) that in Africa, men are more likely than women to open an account with a formal financial institution.

With regard to age as a variable as indicated in Table1, 205 respondents were between 18 and 30 years all inclusive representing 41.36 percent followed by 31- 40 year group with 152 all inclusive representing 30.04 percent. Also, between the ages of 41 and 50 all inclusive, there were 96 customers representing 19.20 percent of respondents in that age group. Moreover, those above the age 51 years were 47 representing 9.40 percent of the respondents sampled for the study. This result indicates that majority of the respondents fall within the youth and the economically active population cohorts (thus 18-50 years) having a cumulative frequency of 453 . This result is consistent with the finding of Abbam, Say and Carmaser (2015). The finding of Abbam and Say indicated that 77.10 percent of 660 bank customers in Winneba, sampled as respondents to determine their choice of commercial bank, were within the age bracket of 18-49 years.

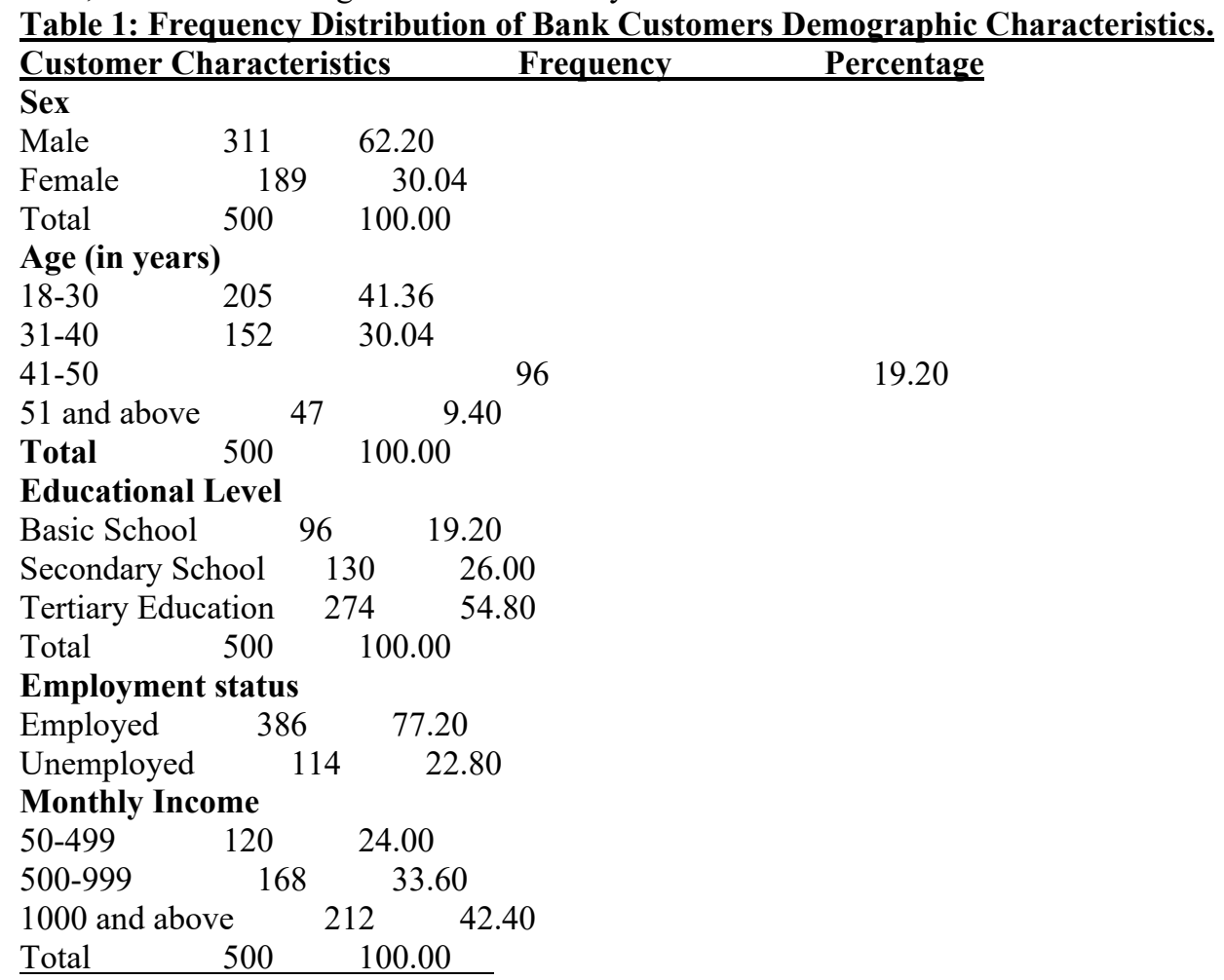

Source: Field Survey, 2020

The result also, shows that majority of the respondents, thus $274(54.80 \%)$, had attained tertiary education as presented by Table1. Additionally, $130(26.00 \%)$ had attained secondary education and had acquired Basic education. This result indicates that formal banking habit is high among the educated elites in the Mfantseman Municipality.

As far as the employment variable is concerned, the study disclosed that $386(77.20 \%)$ of the respondents were gainfully employed. For the respondents who were unemployed, majority of them thus $114(22.80 \%)$ were students. This presents a great opportunity and future prospect foe banks operating in the Mfantseman Municipality and in Ghana as a whole. This result is also consistent with the finding of Katircioglu (2011) that undergraduate students are future potential customers of commercial banks.

\subsection{Regression Analysis on the Factors that affect Bank Selection Decision}

Given the nominal nature of the dependent variable, customer's bank selection decision, multinomial logistic regression is employed for this analysis. The study focuses on four main variables - branding, location of banks, electronic products offered by banks and advertising - and how they influence bank selection decision. This section presents findings from the regression analysis on the main variables and that of other covariates such as age and income and type of labour, whether skilled or unskilled. The results have been presented in Table 2 below. 
Table2 Multinomial Logistic Regression Output

\begin{tabular}{|c|c|c|c|c|}
\hline Variable & RRR & Std. Err. & $\mathrm{z}$ & $\mathrm{P}>\mathrm{Z}$ \\
\hline \multicolumn{5}{|l|}{ opportunity } \\
\hline Age & 1.0162 & 0.0308 & 0.5300 & 0.5960 \\
\hline Employed & 6.9874 & 6.8337 & 1.9900 & 0.0470 \\
\hline Income & 1.0010 & 0.0013 & 0.7700 & 0.4400 \\
\hline Brand & 0.9114 & 0.2504 & -0.3400 & 0.7360 \\
\hline Location & 0.3264 & 0.0892 & -4.1000 & 0.0000 \\
\hline Products \& Services & 0.1624 & 0.0474 & -6.2300 & 0.0000 \\
\hline Advertising & 1.0663 & 0.2017 & 0.3400 & 0.7340 \\
\hline Skilled Labour & 22.9762 & 1720.0000 & 0.0200 & 0.9840 \\
\hline \multicolumn{5}{|l|}{ ADB } \\
\hline Age & 1.0117 & 0.0451 & 0.2600 & 0.7940 \\
\hline Employed & 0.2851 & 0.3077 & -1.1600 & 0.2450 \\
\hline Income & 1.0019 & 0.0019 & 1.0100 & 0.3130 \\
\hline Brand & 0.4199 & 0.1188 & -3.0700 & 0.0020 \\
\hline Location & 0.5381 & 0.1971 & -1.6900 & 0.0910 \\
\hline Products \& Services & 0.2435 & 0.0850 & -4.0500 & 0.0000 \\
\hline Advertising & 0.5886 & 0.1341 & -2.3300 & 0.0200 \\
\hline Skilled Labour & 0.1028 & 0.0926 & -2.5200 & 0.0120 \\
\hline \multicolumn{5}{|l|}{ Microfin } \\
\hline Age & 1.1022 & 0.0446 & 2.4000 & 0.0160 \\
\hline Employed & 1.7440 & 4.3305 & 0.2200 & 0.8230 \\
\hline Income & 1.0012 & 0.0020 & 0.6000 & 0.5500 \\
\hline Brand & 1.0524 & 0.4285 & 0.1300 & 0.9000 \\
\hline Location & 0.2840 & 0.1329 & -2.6900 & 0.0070 \\
\hline Products \& Services & 0.6131 & 0.4462 & -0.6700 & 0.5010 \\
\hline Advertising & 3.4862 & 1.2688 & 3.4300 & 0.0010 \\
\hline Skilled Labour & 0.0045 & 0.0045 & -5.4200 & 0.0000 \\
\hline \multicolumn{5}{|l|}{ NAB } \\
\hline Age & 1.0210 & 0.0447 & 0.4800 & 0.6350 \\
\hline Employed & 0.8400 & 907.0000 & 0.0200 & 0.9870 \\
\hline Income & 0.9945 & 0.0023 & -2.4100 & 0.0160 \\
\hline Brand & 0.3693 & 0.0978 & -3.7600 & 0.0000 \\
\hline Location & 0.2949 & 0.0929 & -3.8700 & 0.0000 \\
\hline Products \& Services & 0.2651 & 0.0917 & -3.8400 & 0.0000 \\
\hline Advertising & 2.0584 & 0.6272 & 2.3700 & 0.0180 \\
\hline Skilled Labour & 15.2209 & 19.0816 & 2.1700 & 0.0300 \\
\hline
\end{tabular}

$\mathrm{N}=332$; LR Chi2 (32)=435.32; Prob $>$ chi2-0.000; Pseudo R2=0.4686

The pseudo $\mathrm{R}^{2}=0.4686$ indicates that 46.86 percent of the variations in bank selection decision is explained by the model. The F-statistic $((\mathrm{F}=435.32$, Prob $>$ chi $=0.000)$ shows that there is strong and significant relationship between choice of bank and its explanatory variables. These figures provide evidence of model fit, indicating particularly that the regression model fitted the data reasonably well. From the results, the p-values associated with the likelihood ratio test indicate that the coefficient for age (chi2 $=6.640, \mathrm{p}>\mathrm{chi}=0.355)$ and income (chi2 $=$ $10.726, \mathrm{p}>\mathrm{chi}=0.097$ ) of respondents in the multinomial logistic equation is not significantly different from zero (0) at $5 \%$ level of significance. That is, age and income do not statistically explain the choice of bank in this study. However, all other variables in the model passed the likelihood ratio test. Therefore we proceed to interpret the results obtained for these variables.

The base category for the multinomial logistic regression for this study is GCB bank limited (GCB). Therefore we analyse all other categories in reference to GCB. For choice of Opportunity International relative to choice of $\mathrm{GCB}$, the $\mathrm{z}$ test statistic for the dummy predictor, employment (1.99), - whether employed or unemployed -is associated with a p-value of 0.047 . At alpha level of $5 \%$, we fail to accept the null hypothesis and conclude that for choice of Opportunity International relative to GCB the regression coefficient for employment has been found to be statistically different from zero given other factors in the model. The relative probability of choosing Opportunity International compared to GCB is $59.8 \%$ higher for those employed in the informal sector. Stated differently, all other things being equal, people who are employed in the informal sector are more likely to choose Opportunity International than GCB. This because Opportunity International usually offer loans to people in the SME sector.

Another factor that influences the choice of Opportunity International compared to GCB from the results is 
convenient location. By location we mean the number of branches of the bank, the proximity to the central business district, market place, work place or home. The $z$ test score for this variable $(-4.10)$ is associated with a p-value of 0.000 which lead us to reject the null hypothesis at $1 \%$ level of significance. The relative risk shows that a unit increase in considering number of branches of a bank, proximity to central business district, market place, work place and/or home reduces the relative probability of choosing Opportunity International compared to GCB by $67.36 \%$ (1-0.3264). That is, when we take location of bank in terms of number of branches, and proximity to key places one is more likely to choose GCB rather than Opportunity International, all other things being equal. GCB Bank has two branches in the most busy and populous cities (Mankessim and Saltpond) and also operate two ATM points in the Municipality while opportunity International has only one branch in the Mfantseman Municipality. Also, GCB is the first financial institution to set up an operational branch in the Mfantseman Municipality. This finding confirms the study of Maiyaki (2011) that convenient and easy access to bank location has great influence on customers' choice of bank.

Last but not least, products and services - ATM services, internet and mobile banking, interest on savings and bank charges offered by banks explain the choice of Opportunity International relative to GCB. The $\mathrm{z}$ test score for this variable (-6.23) is associated with a p-value of 0.000 which lead us to reject the null hypothesis at $1 \%$ level of significance. All other things being equal, a unit increase in considering the products and services offered by a bank decreases the relative probability for choosing Opportunity International compared to GCB by $83.76 \%$ (10.1624). That is, by considering the products offered by banks, people of Mfantseman Municipality are more likely to choose GCB than Opportunity International. GCB offers a wide variety of products such salary loan, G-money which is not offered by Opportunity to it customers. This result is consistent with the finding of Agbemabiese, Anim and Nyanyofio (2015) that mobile banking influence customers of Access bank in choosing it as their primary bank.

For factors that affect the choice of Agricultural Development Bank (ADB) compared to GCB, are branding, location, products and services, and advertising which were found to be statistically significant. The $\mathrm{z}$ test statistic for branding $(-3.07)$ is associated with a p-value of 0.002 which lead us to reject the null hypothesis that branding does not affect the choice of ADB compared to GCB at 1\% level of significance. The relative risk ratio for choosing $\mathrm{ADB}$ is $58.01 \%$ (1-0.4199) lower compared to GCB if there is a unit increase in considering branding when choosing a bank, all other things remaining constant. More generally, in Ghana, by considering branding when choosing a bank, it is more likely to choose GCB than ADB all other things being equal. GCB is considered as one of the top banks in Ghana due to its strong financial viability. It has therefore, earned high image and reputation in the heart of many Ghanaians. This result confirms the finding of Ansa (2014) that brand name and reputation influence the decision of senior high school teachers in the Kumasi Metropolis when selecting bank for financial transactions nancial viability. It is one of the few banks which gives loan to even the government of Ghana.

Location of bank defined by its number of branches and proximity to workplace/home/market/CBD has also been found to significantly affect the choice of ADB compared to GCB. The $\mathrm{z}$ test statistic of this predictor (-1.69) is associated with a p-value of 0.091 . This suggests that the null hypothesis that location of banks does not affect the choice of ADB relative to GCB can be rejected at $10 \%$ level of significance. The relative risk for choosing ADB is $46.19 \%$ (1-0.5381) is lower compared to GCB if there is a unit increase in considering location of banks all other things being equal. That is, all other things being equal, if there is an increase in considering location when choosing a bank, the likelihood of choosing ADB falls when compared to a GCB. More generally, in Ghana, by considering location of banks, it is less likely for a person to ADB compared to GCB. GCB has more branches than ADB in the Mfantseman Municipality. This result corroborates the finding of Kisser (2002) that People may prefer to select the nearest branch of a bank from either residential place or work place.

Also among the significant factors that affect the choice of ADB relative to GCB is products and services offered by the banks to their customers. The regression results as shown in Table 2 reveals that the $\mathrm{z}$ test statistic $(-4.05)$ is associated with a p-value of 0.000 which leads us to reject the null hypothesis at $1 \%$ level of significance. For a unit increase in considering location of banks, the relative probability of choosing ADB compared to GCB falls by $75.65 \%(1-0.2435)$ all other things being equal. That is, when there is an increase in considering location of banks before making a choice, the relative probability of choosing ADB is lower compared to GCB. GCB offers lots of Products such as G-money and Saturday Banking which are not offered by ADB.

The choice of ADB compared to GCB is again partly dependent on advertising. The results in Table 2 reveals that the $\mathrm{z}$ test statistic for advertising $(-2.33)$ is associated with a $\mathrm{p}$-value of 0.02 . This means that advertising significantly explains the choice of ADB relative to GCB at 5\% level of significance. The relative risk ratio for ADB is $41.14 \%$ (1-0.5886) lower compared to GCB if there is a unit increase in considering advertising when choosing a bank in Ghana all other things being equal. More generally, the results suggest that the relative probability of choosing ADB is lower compared GCB when we consider advertising when choosing a bank, all other things remaining constant. GCB runs aggressive advertisement of its products in its extensive branches nationwide and through electronic, print and social media. This Makes GCB a notable bank in most of the households in Ghana as compared to ADB. This result is in line with the finding of Abdul and Omar (2010) that 
advertising by banks highly influence customers to patronize the products and the services of that particular bank.

The results of the regression analysis shown in Table2 reveal that Location, advertising Microfin bank relative to GCB. The predictor Location of banks defined by number bank's branches and proximity to key areas has a $\mathrm{z}$ test statistic of -2.41 and is associated with a p-value of 0.007 . This leads us to reject the null hypothesis at $1 \%$ level of significance. If there is a unit increase in considering bank's location in choosing a bank, the relative probability for choosing Microfin is $71.60 \%(1-0.2840)$ lower compared to GCB. More generally, in Ghana, it is less likely to choose Microfin compared to GCB when considering location of banks. GCB has lots of branches and they are conveniently located compared to Microfin. It is therefore not surprising that bank customers in the Mfantseman Municipality are more likely to choose GCB as compared to Microfin when location is considered. This result is consistent with the finding of Salleh \&Hazimah (2009) that convenient location of ATM and parking space are some of the factors that help to retain and attract more customers

Advertising is another factor that explains the choice of Microfin compared to GCB. At 1\% level of significance, we reject the null hypothesis that advertising does not affect the choice of Microfin bank compared to GCB all other things being equal. This is revealed by the $\mathrm{z}$ test statistic associated with this predictor (3.43) and the corresponding $\mathrm{p}$-value of 0.001 . The results suggest advertising influences the choice of Microfin bank more than GCB. The relative probability for choosing Microfin compared to GCB increases by a factor of 3.486 if there is a unit increase in considering advertising when choosing a bank. From the results it can be implied that compared to GCB, Microfin bank can attract more customers by advertising their products on all forms of media available. Mirofin is one of the new financial institutions operating in the municipality and Ghana as a whole. This means that the bank need to make lots of advertisement so as to attract more customers. This result also affirm the finding of Mokhlis (2009) that advertising by banks in the form of marketing promotion influence bank preference to both males and females.

Among the factors that affect the choice of Nyankomase Ahenkro Bank relative to GCB are branding, location of banks, products and services, advertising. Table 2 reveals that the $\mathrm{z}$ test statistic for the predictor, branding (3.76 ) is associated with a p-value of 0.000 . This leads us to reject the null hypothesis at $1 \%$ level of significance. A unit increase in considering branding causes the relative probability of choosing Nyankomase Ahenkro Bank relative to GCB to decrease by $63.07 \%$ (1-0.3693). That is, it is less likely for respondents to choose Nyankomase Ahenkro Bank compared to GCB on the basis of brand image, all other things being equal. GCB is financially stable than Nyankomase Ahenkro Bank. This makes GCB a preferred bank to Nyankomase Ahenkro Bank by customers in the municipality. This is because people are safe to save their money with GCB compared to Nyankomase Ahenkro Bank. This result corroborates the finding of Kumar, Kee and Charles (2010) that safety of fund is the most important factor considered by customers when selecting banks for their financial transaction.

Another factor that explains the choice of Nyankomase Ahenkro Bank relative to GCB is location. The $\mathrm{z}$ test score for this predictor (-3.87) is associated with a p-value of 0.000 which lead us to reject the null hypothesis at $1 \%$ level of significance. The relative risk shows that a unit increase in considering number of branches of a bank, proximity to central business district, market place, work place and/or home reduces the relative probability of choosing Nyankomase Ahenkro Bank compared to GCB by $70.51 \%$ (1-0.2949). That is, when we take location of bank in terms of number of branches, and proximity to key places one is more likely to choose GCB rather than Nyankomase Ahenkro Bank all other things being. GCB has more branches in the Mfanfseman Municipality and in Ghana as a whole compared Nyankomase Ahenkro Bank. This means that customers of GCB are more likely to have access to their money as compared to Nyankomase Ahenkro Bank due to the extensive branch network of GCB. This finding affirms the study of Maiyaki (2011) that convenient and easy access to bank location has great influence on customers' choice of bank.

Also among the significant factors that affect the choice of Nyankomase Ahenkro Bank relative to GCB is products and services offered by the banks to their customers. The regression results as shown in Table 2 reveals that the $\mathrm{z}$ test statistic $(-3.43)$ is associated with a p-value of 0.001 which leads us to reject the null hypothesis at $1 \%$ level of significance. For a unit increase in considering location of banks, the relative probability of choosing Nyankomase Ahenkro Bank compared to GCB falls by $73.49 \%$ (1-0.2651) all other things being equal. That is, when there is an increase in considering location of banks before making a choice, the relative probability of choosing Nyankomase Ahenkro Bank is lower compared to GCB.

The choice of Nyankomase Ahenkro Bank compared to GCB is again partly dependent on advertising. The results in Table2 reveal that the $\mathrm{z}$ test statistic for advertising $(2.37)$ is associated with a p-value of 0.018 . This means that advertising significantly explains the choice of Nyankomase Ahenkro Bank relative to GCB at 5\% level of significance. The relative risk ratio for Nyankomase Ahenkro Bank increases by a factor of 2.06 compared to GCB if there is a unit increase in considering advertising when choosing a bank in Ghana all other things being equal. More generally, the results suggest that the relative probability of choosing Nyankomase Ahenkro Bank is higher compared GCB when we consider advertising when choosing a bank, all other things remaining constant. 


\subsection{Conclusions}

Based on the analysis and the results of the study, the following conclusions are made for further considerations. In the wake of banking crises and increasing call on government of Ghana to improve upon the standard of living of the citizenry, it has become imperative for researchers to engage in in-depth investigation into the potential factors that can influence the speedy realization of this dream. The effort by government and other state bodies to improve upon the economy and help to reduce the poverty level in Ghana encompasses the development of all sectors of the economy with which the financial sector is not an exception. In as much as the government is playing instrumental role in this campaign, the financial institutions are also strategizing very effectively to take advantage of all the opportunities that come with the national campaign to increase their customer base. These strategies have included rebranding of the institutions, development of innovative products and effective advertisement.

Based on the results of the study, the following observations were made: It was observed that advertising turns out to be a significant predictor of the customers' bank selection decision, meaning that there is a positive association between advertising and bank selection decision as it has been indicated in the literature. This result confirms the hypothesis set for advertising as a variable for this study to be investigated.

It was also observed that there was a positive association between branding (reputation) and bank selection decision. This finding is interpreted with caution given the fact that its effect is dependent on the subjective, rather than objective, judgment of potential customers of Banks.

It was observed that convenient location of a bank is significant in explaining customers' bank selection decision. However, there is a negative relationship between distance to bank location and customers' bank selection decision. This indicates that as the distance to the nearest bank branch increases, the probability of transacting business with a bank reduces with the appropriate marginal effect. This result also confirmed the hypothesis formulated to be tested for the study.

In terms of innovative products and customers' choice of bank, it was observed that innovative product was an important predictor, and it was significant in explaining the customers' choice of bank in the Mfantsiman Municipality. There was a positive relationship between electronic product and customers' bank selection decision, thereby confirming the hypothesis formulated for the study as well. Also, other demographic characteristics of customers that significantly predicted bank selection decision were occupation and education.

This study, therefore, serves as a basis for further research into the potential effect of branding, advertising and other marketing strategies in influencing the course of campaign for Ghanaians to transact business with financial institutions. The study is also anticipated to add to the existing and growing body of literature of factors influencing customers' bank selection decision and switching behaviour. It is expected that other studies that will be done in the near future will draw lessons from and build up this study so that enhanced understanding can be gained on the factors that influence customers' decision in the banking industry in Ghana.

\subsection{Recommendations}

Based on the results and the findings of this study, a number of recommendations are made to government, bank managers, customers and other stakeholders in the banking industry.

Banks should improve upon their corporate brands, reputation and financial stability. Thus, banks operating in Ghana should improve upon their image, reputation and financial standing. This would help customers to avoid cognitive dissonance after they have transacted business with the banks.

Banks should improve upon their advertising campaign. This will help customers to know more about the products and services offered by the banks so as to attract more customers and maintain the existing customer base.

The study, also, advocates that banks should extend their branch networks especially to the local communities. This will help to bring banking to the door steps of the ordinary Ghanaian and help to improve banking penetration in the country as well.

Additionally, banks should embrace well-integrated application of technology and current ways of delivering banking services to their customers. Electronic products such as Automated teller machines should be installed at marketplaces, shopping malls and other important places across the length and breadth of the country. Internet banking, mobile banking and E-zwich services should be employed by the banks to help promote the call of government to establish a cashless economy. Banks should also adopt innovative products and services, such as, the national E-zwich and other biometric cards, as means of attracting new and retaining existing customers, so as to improve upon their penetration ratio in the country.

\section{Refrences}

Abbam, A., Say, J., \& Carsamer E. (2015).An analysis of choice of commercial banks among university students in Ghana, International Journal of Economics, Commerce and Management, 3(2), 9-10.

Abduh, M., \& Omar M. A. (2010). Who Patronizes Islamic Banks in Indonesia, The International Conference on Business and Economics, April 15-16, Andalas University, Indonesia.

Abor, J. (2004). Technological innovations and banking in Ghana: An evaluation of customers' perceptions. 
American Academy of Financial Management, 2(1), 1-16. Retrieved June 10, 2019, from http://www.financialcertified.com/armstrong.html

Almossawi, M. (2001). "Bank selection criteria employed by college students in Bahrain: an empirical analysis", International Journal of Bank Marketing, 19(3), 115-25.

Anon, D. (2011) Sex and Advertising: Retail Therapy.The Economist. Retrieved July 4, 2019, from http://www.economist.com/node/21541706

Arebgeyen, O. (2011). The Determinants of Bank Selection Choices by Customers: Recent and Extensive Evidence from Nigeria, International Journal of Business and Social Science, 2(22), 12-15.

Atta-Junior D., Osei B., \&Pertershie, B. (2013), Factors Affecting Customers Choice of Retail Bnaking in Ghana: International Research on Social Science; 3 (1)

Baker, K. A. (2002). Organizational Communication in Management Benchmark Study/U.S. Office of Science/Department of Energy. Retrieved May 25, 2019, from http://www.au.af.mil/au/awc/awcgate/doe/benchmark/

Bandural, A. (1997). Self-efficacy: The exercise of control. New York: W.H. Freemen.

Beckett, A., Hewer, P., \& Howcroft, B. (2003), "An exposition of consumer behaviour in the financial services industry", International Journal of Bank Marketing, 18(1), 15-26.

Blankson C., Omar O. E., \&Cheng J. M. (2009), The Retail Bank Selection in Developed and Developing Countries: A Cross-National Study of Students' Bank- Selection Criteria, Thunderbird International Business Review, 51( 2), 183-98.

Bravo, R., Montaner, \&Pina, J. M. (2010). Corporate brand image in retail banking: development and validation of a scale. The Service Industries Journal, 30 (8), 1199-1218.

Bramorski, T., Madan, M.S., \&Motwani, J. (2002). Application of the Theory of Constraints in Banks. Retrieved on May 19, 2015, from http: //www.tocca.com.

Creswell J. W. (2009), Research Design: Qualitative, Quantitative, and Mixed Methods Approaches, second edition.

Clemes. M. D., Gan, C., \& Zhang, D. (2010).Customer switching behaviour in the Chinese retail banking industry, International Journal of bank marketing, 28(7), 519-546.

Cleopas, C., \& Olawale, F. (2011). Factors Influencing the Choice of Commercial Banks by University Students in South Africa, International Journal of Business and Management, 6(6), 66-76

Cohen, L., Manion, \& Morrison, K. (2011).Research Methods in Education. Reoutledge

Colgate, M., Tong, V. T. U., Lee, C. K. C., \& Farley, J. U. (2007). Back from the brink: why customers stay. Journal of Service Research, 9(3), 211-228.

Delvin, N., \&McKechnie, S. (2008). Modelling consumer choice of distribution channels: an illustration from financial services. International Journal of Bank Marketing, 20(4), 161-173.

Demirguc-Kunt, A., \& Klapper L. (2012).Measuring Financial Inclusion: The Global Findex Database. Policy Research Working Paper, World Bank, Washington, DC.

Dusuki, A. W., \& Abdullah N. I. (2007).Why do Malaysian Customers Patronize Islamic banks? International Journal of Bank Marketing, 25(3),142-160.

Farooq S. U., Ahmad G., \&Jamil S. H. (2010).Profile Analysis of the Customers of Islamic Banking in Peshawar, Pukhtunkhwa, International Journal of Business and Management, 5 (11), 106-171

Ganesh, J., Arnold, M.J., \& Reynolds, K.E. (2000).Understanding the customer base of service providers: an examination of the differences between switchers and stayers. Journal of Marketing, 64(3), 65-87.

Ghana Statistical Service. (2014). 2010 population and housing census provisional results: Summary of findings. Accra, Ghana: Ghana Statistical Service. Retrieved October 2014, from www.modernghana.com.

Graves, P. (2010) Consumer ology; The Market Research Myth, the Truth about Consumers and the Psychology of Shopping, UK: Nicholas Brealey Publishing.

Gerrard, P., \&Cunninham, J. B. (2004).Consumer switching behaviour in the Asian market. Journal of Services Marketing, Vol.18, 3, pp.215-223.

Hinson, R., \& Hammond, B. (2006).Service delivery in Ghana's banking sector, (2 ${ }^{\text {nd }}$ Ed.), African Marketing Practice Cases from Ghana, GH: Sedco Publishing.

Jansson- Boyd, C. (2010) Consumer Psychology, USA: McGraw- Hill Companies

Jayawarhena, C., \& Foley, P. (2000).Changes in the Banking Sector-the case of internet banking in the UK, Internet Research, 10(3), 19-30

Jobber, D.,\&Fahy, J. (2009). Foundations of Marketing.Second edition. Berkshire: McGraw-Hill Higher Education.

Joseph, M., \& Stone, G. (2003). An empirical evaluation of US bank customer perceptions of the impact of technology on service delivery in the banking sector. Journal of Retail and Distribution Management, 31(4), 190-202.

Kamakodi, N., \& Khan, B.A. (2008).An insight into factors influencing bank selection decisions of Indian 
Customers, Asia-Pacific Business Review, Jan-March, 2008.

Karjaluoto, H., Mattila, M., \&Pento, T. (2002).Electronic banking in Finland- Consumer beliefs and reaction to new delivery channel, Journal of Financial Marketing, 6(4), 19-25.

Katircioglu S.T., Fethi S., Unlucan D., \&Dalci I. (2011).Bank Selection Factors in the Banking Industry: An Empirical Investigation from Potential Customers in Northern Cyprus, ActaOeconomica, 61 (1) 77-89.

Keller, K. (2009). Building strong brands in a modern marketing communications environment. Journal of Marketing Communications, 15 (2/3), 139-155.

Keller, K. (2008). Strategic Brand Management: Building, Measuring, and Managing Brand Equity, Upper Saddle River, NJ: Prentice-Hall.

Kiser, E.K. (2002), "Household Switching Behaviour at Depository Institutions: Evidence from Survey DATA", Antitrust Bulletin, 47(4), 619-640.

Kotler, P. (2003). Marketing's new paradigm: What's really happening out there? Planning Rev. Special Issue. 20(5), 50-52.

Kotler, P., Brown L., Burton S., Deans K., and Armstrong G. (2010). Marketing Management, 8th ed., AU: Pearson Australia.

Kotler, P. \& Keller, K. L. (2006). Marketing Management (12th ed.). Upper Saddle River, NJ: Prentice Hall.

Kotler, P., \& Keller, K. L. (2009). Marketing Management. (13 $3^{\text {th }}$ ed.) New Jersey: Pearson Education.

Kumar M., Kee F. T., \& Charles V. (2010), Comparative Evaluation of Critical

Factors in Delivering Service Quality of Banks: An Application of Dominance Analysis in Modified Servqual Model, International Journal of Quality \& Reliability Management. 27(3), 351-377.

Leach, M., Hennesy, M., \&Fishbein, M. (2001). Perception of easy-difficulty: Attitude or self efficacy? Journal of Applied Social Psychology,3(1), 1-20.

Lead E. (2005). Developing an Effective Branding Strategy. Retrieved January 2, 2016, from http://www.leadedge.co.uk.

Lee, J., \& Marlowe, J. (2003).How Consumers Choose a Financial Institution: Decision Making Criteria and Heuristics: International Journal of Bank Marketing, 21(2), 53-71,

Taylor, G. A., Roos, I., \&Hamer, L. (2009).Service separation anxiety: Understanding consumer reaction to involuntary switching. Retrieved from http www.ihroos.fi/switching.html

Littler, D., \&Melanthiou, D. (2006). Consumer perceptions of risk and uncertainty and the implications for behaviour towards innovative retail services. The case of internet banking. Journal of Retail Consumer Services, 13 (2), 431-443.

Long, J S., \& Freese, J. (2014). Regression Models for categorical variables using Stata. $3^{\text {rd }}$ ed. College station, TX: Stata Press.

Lymperopoulos C., Chaniotakis I. E., \&Soureli, M. (2006). The Importance of Service Quality in Bank Selection for Mortgage Loans, Managing Service Quality, 16(4), 365-379.

Mabin, V., \& Balderstone, S. (2003).The performance of the theory of constraints methodology: Analysis and discussion of successful TOC applications. International Journal of Operations\& Production Management, 23(6), 568-595.

Maiyaki, A. A. (2011). Factors Determining Bank's Selection and Preference in Nigerian Retail Banking, International Journal of Business and Management, 6(1), 253-357.

Mokhlis S., Mat, N., \& Salleh H. (2010).Ethnicity and Choice Criteria in Retail Banking: A Malaysian Perspective, International Journal of Business and Management, 5(2), 6-7.

Mokhlis S., Salleh H., \& Mat N. (2009).Commercial Bank Selection: Comparison between Single and Multiple Bank Users in Malaysia, European Journal of Economics, Finance and Administrative Sciences, 1(2), 263273.

Mylonakis, J. (2007). A Research Study of Customer Preferences in the Home Loans Market: The Mortgage Experience of Greek Bank Customers, International Research Journal of Finance and Economics, 10 (1), 153-166,

Oyeniyi O. J., \& Abiodun A. J. (2010). Switching cost and customers' loyalty in the mobile phone market: The Nigerian experience. Journal of Business Intelligence, 3(1), 111-121.

Rao, A.S., \& Sharma, R.K (2010). "Bank Selection Criteria Employed by MBA Students in Delhi: An Empirical Analysis", Journal of Business Studies, 1(2), 56-69.

Rahman, H., \& Ahmed S. (2008). An Empirical Analysis of the Determinants of Bank Selection in Pakistan: A Customer View, Pakistan Economic and Social Review, 46(2), 147-160.

Rhodes, R. E., \& Courneya K. S. (2003). Self-efficacy, controllability and intention in the theory of planned behaviour. Measurement redundancy or casual independence? Psychology and Health, 18, 79-92.

Salleh. H. S., \& Hazimah. N. (2009). Commercial bank selection: comparison between single and multiple bank users in Malaysia. International Journal of Economics and Finance, 1(2), 80-100

Saunders M., Lewis P., \&Thornhill A. (2007). Research methods for business students. England: Pearson 
Professional Limited.

Shaher T. A., Kasawneh O., \& Salem R. (2011). The major factors that affect Banks' Performance in Middle Eastern Countries, Journal of Money, Investment and Banking, 2(3), 101-119.

Sweeney, A., \& Morrison, M. (2004). Clicks vs. Bricks: internet-facilitated relationships in financial services. International Journal of Internet Marketing and Advertising, 1(4), 350-370.

Sutherland M. (2008). Advertising and the mind of the consumer; what works, what doesn't and why, (3rd ) ed., AU: Allen \&Unwin.

World Bank (2012). Financial inclusion in Africa. World Development Report. Washington D.C.

\section{Appendix}

Table 1: Frequency Distribution of Bank Customers Demographic Characteristics.

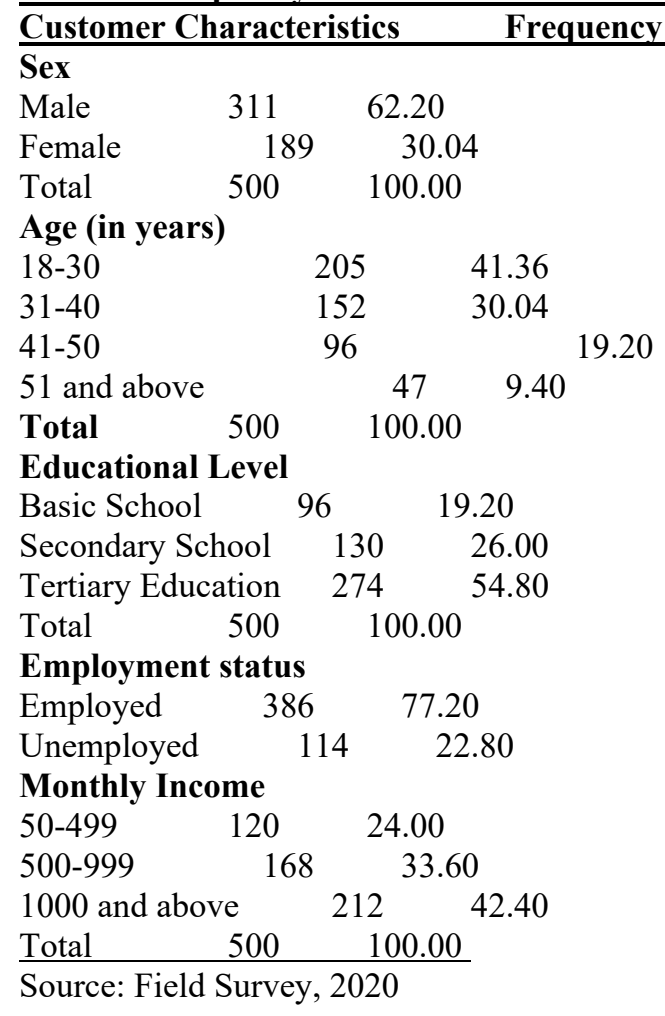


Table2 Multinomial Logistic Regression Output

\begin{tabular}{|c|c|c|c|c|}
\hline Variable & RRR & Std. Err. & $\mathrm{z}$ & $\mathrm{P}>\mathrm{Z}$ \\
\hline \multicolumn{5}{|l|}{ opportunity } \\
\hline Age & 1.0162 & 0.0308 & 0.5300 & 0.5960 \\
\hline Employed & 6.9874 & 6.8337 & 1.9900 & 0.0470 \\
\hline Income & 1.0010 & 0.0013 & 0.7700 & 0.4400 \\
\hline Brand & 0.9114 & 0.2504 & -0.3400 & 0.7360 \\
\hline Location & 0.3264 & 0.0892 & -4.1000 & 0.0000 \\
\hline Products \& Services & 0.1624 & 0.0474 & -6.2300 & 0.0000 \\
\hline Advertising & 1.0663 & 0.2017 & 0.3400 & 0.7340 \\
\hline Labour & 22.9762 & 1720.0000 & 0.0200 & 0.9840 \\
\hline \multicolumn{5}{|l|}{ ADB } \\
\hline Age & 1.0117 & 0.0451 & 0.2600 & 0.7940 \\
\hline Employed & 0.2851 & 0.3077 & -1.1600 & 0.2450 \\
\hline Income & 1.0019 & 0.0019 & 1.0100 & 0.3130 \\
\hline Brand & 0.4199 & 0.1188 & -3.0700 & 0.0020 \\
\hline Location & 0.5381 & 0.1971 & -1.6900 & 0.0910 \\
\hline Products \& Services & 0.2435 & 0.0850 & -4.0500 & 0.0000 \\
\hline Advertising & 0.5886 & 0.1341 & -2.3300 & 0.0200 \\
\hline Labour & 0.1028 & 0.0926 & -2.5200 & 0.0120 \\
\hline \multicolumn{5}{|l|}{ Microfin } \\
\hline Age & 1.1022 & 0.0446 & 2.4000 & 0.0160 \\
\hline Employed & 1.7440 & 4.3305 & 0.2200 & 0.8230 \\
\hline Income & 1.0012 & 0.0020 & 0.6000 & 0.5500 \\
\hline Brand & 1.0524 & 0.4285 & 0.1300 & 0.9000 \\
\hline Location & 0.2840 & 0.1329 & -2.6900 & 0.0070 \\
\hline Products \& Services & 0.6131 & 0.4462 & -0.6700 & 0.5010 \\
\hline Advertising & 3.4862 & 1.2688 & 3.4300 & 0.0010 \\
\hline Labour & 0.0045 & 0.0045 & -5.4200 & 0.0000 \\
\hline \multicolumn{5}{|l|}{ NAB } \\
\hline Age & 1.0210 & 0.0447 & 0.4800 & 0.6350 \\
\hline Employed & 0.8400 & 907.0000 & 0.0200 & 0.9870 \\
\hline Income & 0.9945 & 0.0023 & -2.4100 & 0.0160 \\
\hline Brand & 0.3693 & 0.0978 & -3.7600 & 0.0000 \\
\hline Location & 0.2949 & 0.0929 & -3.8700 & 0.0000 \\
\hline Products \& Services & 0.2651 & 0.0917 & -3.8400 & 0.0000 \\
\hline Advertising & 2.0584 & 0.6272 & 2.3700 & 0.0180 \\
\hline Labour & 15.2209 & 19.0816 & 2.1700 & 0.0300 \\
\hline
\end{tabular}

$\mathrm{N}=332$; LR Chi2 (32)=435.32; Prob $>$ chi2-0.000; Pseudo R2=0.4686

Source: Field Survey, 2020 